\title{
RESEPTOR MELANOKORTIN 1 (MC1R) ASAL USUL DAN STRUKTUR PROTEIN
}

\author{
Gunawan Pratama ${ }^{1}$ \\ Sunny Wangko ${ }^{1}$ \\ Jemima N. Jacobs ${ }^{2}$
}

\author{
${ }^{1}$ Bagian Anatomi Histologi Fakultas Kedokteran Universitas Sam Ratulangi Manado \\ ${ }^{2}$ Bagian Biokimia Fakultas Kedokteran Universitas Sam Ratulangi Manado \\ Email: PzkpfwIVTiger@yahoo.co.id
}

\begin{abstract}
Melanocytes in basal layers of skin and hair follicles produce melanin biopolymers which determine phenotypes of skin and hair colors of an individual. Melanogenesis induction is influenced by many factors: one of them is activation of receptors in melanocytes' transmembrane fragments by effector hormones. Melanocortin-1 receptors belong to the subclasses of the G-protein-coupled-receptor (GPCR) family that is located in melanocytes' transmembrane fragments. Variations of their protein structures affect the end result of skin color. Introduction, nomenclature, grouping these receptors in the GPCR family, and their protein structures, give some important information about how the receptors actually work in our body, especially in the skin and hair.
\end{abstract}

Keywords: GPCR, MC1R, protein's structure

\begin{abstract}
Abstrak: Sel-sel melanosit pada lapisan basal kulit dan folikel rambut memproduksi biopolimer melanin yang akan menentukan fenotip warna kulit dan rambut seseorang. Induksi melanogenesis yang terjadi dipengaruhi oleh banyak faktor, salah satu diantaranya adalah melalui aktivasi reseptor pada transmembran melanosit oleh beberapa hormon efektor. Reseptor melanokortin 1 merupakan sub-sub kelas kelompok reseptor protein G yang terletak pada transmembran melanosit dimana variasi struktur protein penyusunnya akan mempengaruhi hasil akhir warna kulit. Pengenalan awal, tata nama, penggolongannya dalam bagian keluarga besar protein $\mathrm{G}$ serta struktur protein setidaknya memberi sedikit pemahaman bagaimana cara kerja reseptor ini selanjutnya.
\end{abstract}

Kata kunci: MC1R, GPCR, struktur protein

Warna kulit manusia berada dalam variasi dan gradasi yang lebar, dari yang putih ke coklat sampai hitam. Hal ini disebabkan oleh karena adanya pigmen melanin yang diproduksi oleh melanosit dan pigmentasi yang dipengaruhi oleh faktor genetik, lingkungan dan endokrin yang memodulasi jumlah, tipe, dan distribusi melanin di dalam kulit.

Di samping perannya dalam menentukan etnik, melanin sangat penting dalam mempertahankan tubuh terhadap bahaya radiasi sinar ultra ungu. Sintesis melanin ditentukan oleh regulasi yang kompleks dari berbagai aspek, salah satunya adalah melanocortin 1 receptor (MC1R) dengan peptida melanokortik sebagai ligannya.

Pergeseran sintetis eumelanin ke feomelanin dihubungkan oleh mutasi pada MC1R yang mengakibatkan perubahan warna kulit dan meningkatnya faktor resiko genetik kanker kulit melanoma maupun nonmelanoma. ${ }^{1,2,3}$ Ini berarti, proses pigmentasi pada tingkat sel bergantung pada keadaan melanosit, proliferasi dan aktivitas intrasel lainnya.

Pengaturan proliferasi sel, diferensiasi dan migrasi penting untuk susunan dan 
fungsi dari suatu jaringan. Protein-protein pengatur misalnya faktor pertumbuhan/ Growth factors (GF), termasuk hormon berfungsi mengontrol proses sel dan berperan sebagai mediator lintasan sinyal antar sel. Ikatan reseptor pada protein tersebut akan mencetuskan lintasan sinyal transduksi di dalam sel yang selanjutnya akan memberi beragam hasil akhir berupa pengaturan ekspresi gen, pembelahan sel, proliferasi, pergerakan dan proses-proses lainnya.

Telah ditemukan beberapa reseptor yang berperan dalam aktivasi sinyal transduksi oleh faktor pertumbuhan digolongkan dalam suatu keluarga besar dari kelompok reseptor pasangan protein $\mathrm{G}$ $\{G$-Protein Coupled Receptors (GPCR) yang mempresentasikan salah satu dari jenis kelompok reseptor yang telah dikenal luas. ${ }^{4}$

Melanocortin 1 receptor / reseptor melanokortin 1 (MC1R) adalah suatu kelompok reseptor pasangan protein-G (GPCR) transmembran pada melanosit yang menjabarkan fenotip dari pigmen kulit, mengatur berbagai aspek fungsional dari melanosit termasuk stimulasi siklik adenosin monofosfat (cAMP), melanogenesis dan proliferasi. ${ }^{5}$ Suatu endositosis bermedia reseptor, yang terjadi pada melanosit sebagai respon spesifik terhadap hormon peptida \{Adrenokortikotropin hormon (ACTH)/ alfa Melanocyte stimulating Hormone $(\alpha \mathrm{MSH})\}$ adalah syarat utama untuk dapat memulai kaskade melanogenesis, dengan MC1R sebagai gerbang utama. ${ }^{6}$

\section{DEFINISI DAN NOMENKLATUR}

Melanocortin 1 receptor (MC1R) adalah suatu jenis reseptor yang tergolong dalam kelompok reseptor pasangan protein-G $\{G$-Protein coupled receptor (GPCR) $\}$ yang terdapat pada membran melanosit epidermal dan folikel rambut. Keluarga besar jenis reseptor Protein-G ini berfungsi memediasi beragam rangsangan, termasuk cahaya, penghidu, perasa, ion-ion, neurotransmiter dan hormonal. Dalam pengaturan banyaknya sinyal tersebut, GPCR meregulasi aktivitas enzim-enzim metabolik, berbagai lintasan saluran ion, transpor membran, fungsi transkripsi, motilitas dan fungsi sekresi tergantung pada sel dimana protein tersebut berada. Melanocortin 1 receptor khususnya merupakan satu dari kelima jenis subfamili GPCR yang bertugas memediasi aktifitas fisiologi hormon peptida dalam menginduksi aktivasi siklik AMP dalam sitosol melanosit. $^{3}$

Reseptor pasangan protein-G (GPC-R) adalah protein integral membran dikarakteristik dengan adanya tujuh domain hidrofobik transmembran (TM) yang bersamaan membentuk jalinan heliks anti-pararel alfa. Ketujuh transmembran itu ditetapkan sebagai transmembran pertama (TM1), transmembran kedua (TM2), transmembran ketiga (TM3), transmembran keempat (TM4), transmembran kelima (TM5), transmembran keenam (TM6), dan transmembran ketujuh (TM7). ${ }^{4}$

Protein-protein ini bervariasi ukuran yang dibentuk dari 400 sampai 1000 residu asam amino. Terminal amino GPCR terletak ekstrasel, bervariasi panjangnya, dan selalu menjadi tempat glikosilasi. Terminal karboksil terletak di dalam sitoplasma dan menjadi tempat utama fosforilasi.

Telah ditemukan bahwa lengkung ekstrasel GPCR berlawanan arah dengan lengkung intrasel dan menghubungkan domain transmembran. Jembatan disulfida sistein menghubungkan lengkung ekstrasel kedua (el2) dan ketiga (el3) sehingga memungkinkan interaksi dengan agonis atau antagonis ${ }^{4}$.

Penamaan MC1R biasa juga ditulis/ disebutkan dengan berbagai alias antara lain: Melanocortin receptor 1 (MC1-R), Melanotropin receptor MGC14337, melanocortin 1 receptor (MSH-R), melanocortin 1 receptor $\{$ alpha melanocyte stimulating hormone receptor (MSHR)\}, melanocyte stimulating hormone receptor (SHEP2). Gen pengkode MC1R terdapat pada kromosom nomor 16 pada pita q24.3 atau disingkat 16q24.3 dalam sistem pemetaan protein menurut GeneCards ${ }^{\circledR}$ "Weizmann Institute of Science" 7, seperti terlihat pada Gambar 1. 


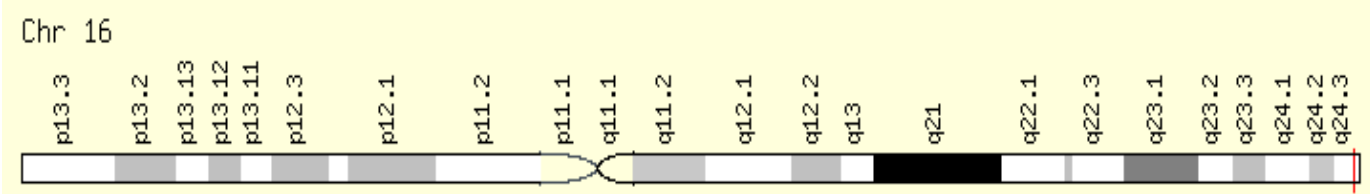

Gambar 1: Gen pengkode MC1R pada pair band q24.3 dalam lokasi genomik kromosom nomor 16. Sumber: The GeneCards Human Gene Database. 2009

\section{KLASIFIKASI}

Kesuksesan evolusioner dari keluarga besar GPCR dicerminkan dari keberadaannya pada setiap organisme eukariot dan sangat berlimpah pada mamalia termasuk manusia. Berdasarkan sekuensi genom manusia dan spesies mamalia lain, diperkirakan terdapat tiga sampai empat persen kode gen untuk GPCR.

Superfamili GPCR dibagi paling tidak lima famili berdasar struktur yang jelas, di antaranya: glutamat, rhodopsin, adhesion, frizzled/ taste dan keluarga secretin. Reseptor-reseptor mirip rodopsin (disebut juga kelas A atau 1) terdapat pada sebagian besar vertebrata. Karena sangat kecilnya sekuensi homologi di antara reseptor-reseptor rhodopsin-like, secretinlike (Kelas $\mathrm{B}$ atau 2), dan glutamat-like (kelas $\mathrm{C}$ atau 3), asal mula evolusioner dari GPCR dan turunannya tetap menjadi persoalan yang masih terus diperdebatkan. ${ }^{8}$

Reseptor melanokortin 1 (MC1R) termasuk dalam GPCR kelas A (rhodopsinlike) subunit alfa dan masih dikelompokkan lagi ke dalam sub-subunit Alfa-s berdasarkan protein $\mathrm{G}$ yang menjadi pasangannya. ${ }^{9}$ Gambar 2 memberi penjelasan ringkas mengenai penggolongan superfamili reseptor pasangan protein-G yang terbagi atas lima kelas utama: A atau 1, B atau 2, C atau 3, D atau 4, dan E atau kelas 5. Sub-unit dibawahnya dibedakan atas alfa, beta, delta dan gama. Sub unit alfa terbagi lagi kedalam sub-sub-unit s, yaitu protein-G stimulate. Reseptor melanokortin termasuk dalam sub-sub-unit tersebut dan terbagi atas lima jenis: reseptor melanokortin 1 (MC1R), reseptor melanokortin 2 (MC2R) atau dengan nama lain reseptor adrenokortikotropin hormon
(ACTR), kemudian reseptor melanokortin 3, 4 dan 5 (MC3R, MC4R, MC5R).

Terdapat lebih dari tiga puluh varian alelik MC1R pada manusia telah diidentifikasi terutama pada populasi Eropa Utara dan Australia. Akan tetapi, konsekuensi varian-varian ini pada fungsi fisiologi MC1R masih sangat kurang dimengerti. Di antara varian-varian tersebut sejauh yang pernah dilaporkan, Arg142His, Arg151 Cys, Arg161Trp, dan Asp294His adalah mutasimutasi alami yang paling sering dihubungkan dengan fenotip rambut merah dan menurunnya kemampuan menggelapnya kulit (tanning ability) pada banyak populasi. ${ }^{1}$

Pada tahun 1995, Valverde dkk. ${ }^{12}$ melaporkan suatu penelitian perbandingan warna kulit berdasarkan wilayah peta du-nia dan mendemonstrasikan bahwa lebih delapan puluh persen dari manusia dengan kulit merah atau kulit pucat memiliki disfungsi varian MC1R. Temuan ini memancing ketertarikan dalam menjelaskan mengapa terdapat prevalensi yang tinggi dari tipe rambut merah dan kulit pucat pada beberapa populasi Eropa Utara, spesifiknya Irlandia dan Inggris.

Suatu hipotesis tentang asal muasal yang berjuluk Out of Africa mengemukakan bahwa manusia masa kini berasal dari Afrika dan bermigrasi ke Utara dan menetap di Eropa dan Asia. Adalah pastinya bahwa para migran ini memiliki varian MC1R aktif dan sesuai dengan itu, kulit dan rambut yang lebih gelap (seperti pada ras Afrika saat ini). Dibandingkan dengan para migran yang menetap di Utara, tekanan selektif yang mempertahankan kulit gelap menjadi kurang sebagaimana halnya intensitas radiasi matahari yang juga menurun. 


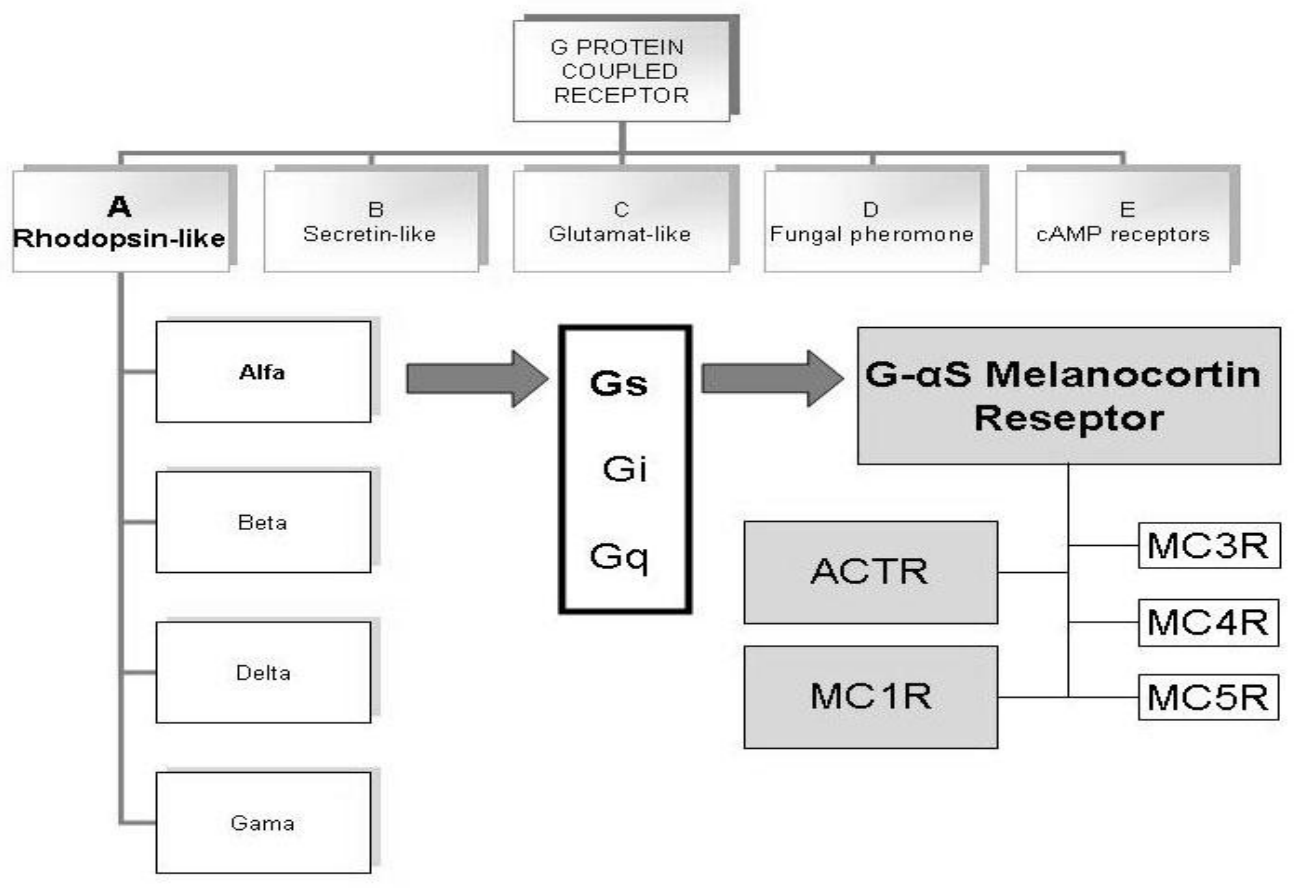

Gambar 2. Diagram penelusuran jalur kelas MC1R sebagai bagian dari superfamili G protein reseptor. Rhodopsin like $=$ GPCR kelas A terbagi atas empat sub-unit alfa, beta, delta dan gama. Reseptor melanokortin merupakan sub-sub-unit dari GPCR kelas A berdasarkan protein G yang menjadi pasangannya yaitu Gs (guanin stimulate) alfa. ACTR=reseptor adrenokortikotropin hormon adalah nama lain dari MC2R (melanocortin 2 receptor) juga termasuk dalam lima jenis reseptor melanokortin. Dirangkum dari: Römpler H et al, 2007. ${ }^{8}$ Kroeze WK et al, 2003..$^{9}$ Michael Riffle, 2009. ${ }^{10}$ Wikipedia® $2009 .{ }^{16}$

Akhirnya variasi MC1R pada populasi manusia mulai muncul dan berakibat pada kulit yang menjadi lebih terang antara lain pada orang Eropa, dan kulit merah. ${ }^{13}$

\section{STRUKTUR PROTEIN}

Berdasarkan analisis kesamaan sekuensial, MC1R dan juga reseptor melanokortin lainnya digolongkan dalam GPCR kelas A dengan rodopsin sebagai prototipnya. Reseptor pasangan protein $\mathrm{G}$ ini resisten terhadap kristalisasi, dan struktur sekunder dan tersier pada dasarnya hanya terbatas pada resolusi rendah mikroskop elektron dari struktur bakterio-rodopsin dan struktur kristal rodopsin. Pada tahun $2000,{ }^{14}$ pertama kalinya struktur kristal GPCR mamalia yaitu rodopsin bovin, telah dapat diuraikan. Sementara ciri utama yaitu tujuh transmembran heliks diawetkan, orientasi relatif dari heliks secara signifikan berbeda dengan bakterio-rodopsin. Baru kemudian pada tahun $2007,{ }^{15}$ struktur GPCR manusia telah selesai diuraikan. MC1R adalah bagian integral membran yang tersusun dari 317 residu asam amino (Gambar 3) dengan struktur khas GPCR seperti antara lain; terminal $\mathrm{N}$ - bagian ekstra sel, tujuh fragmen trans-membran (TM), dan terminal C-pada intra sel. $^{16,17}$

\section{Terminal-N ekstrasel}

Pada umumnya protein membran plasma memiliki N-terminal sebagai sinyal peptida yang menangkap protein bebas ke dalam membran retikulum endoplasma (RE) dan dilepas kembali dengan cepat melalui pemecahan proteolitik. Akan tetapi, terminal-N pada MC1R kurang cocok dengan konsensus sinyal peptida dan penghilangan dari 27 residu asam amino pertama tidak berakibat apapun pada ikatan ligan atau ekspresi sinyal transduksi di dalam sel. Pada MC1R terdapat dua tempat N-terminal terjadinya glikosilasi, ${ }^{15} \mathrm{NSTP}^{18}$ dan 


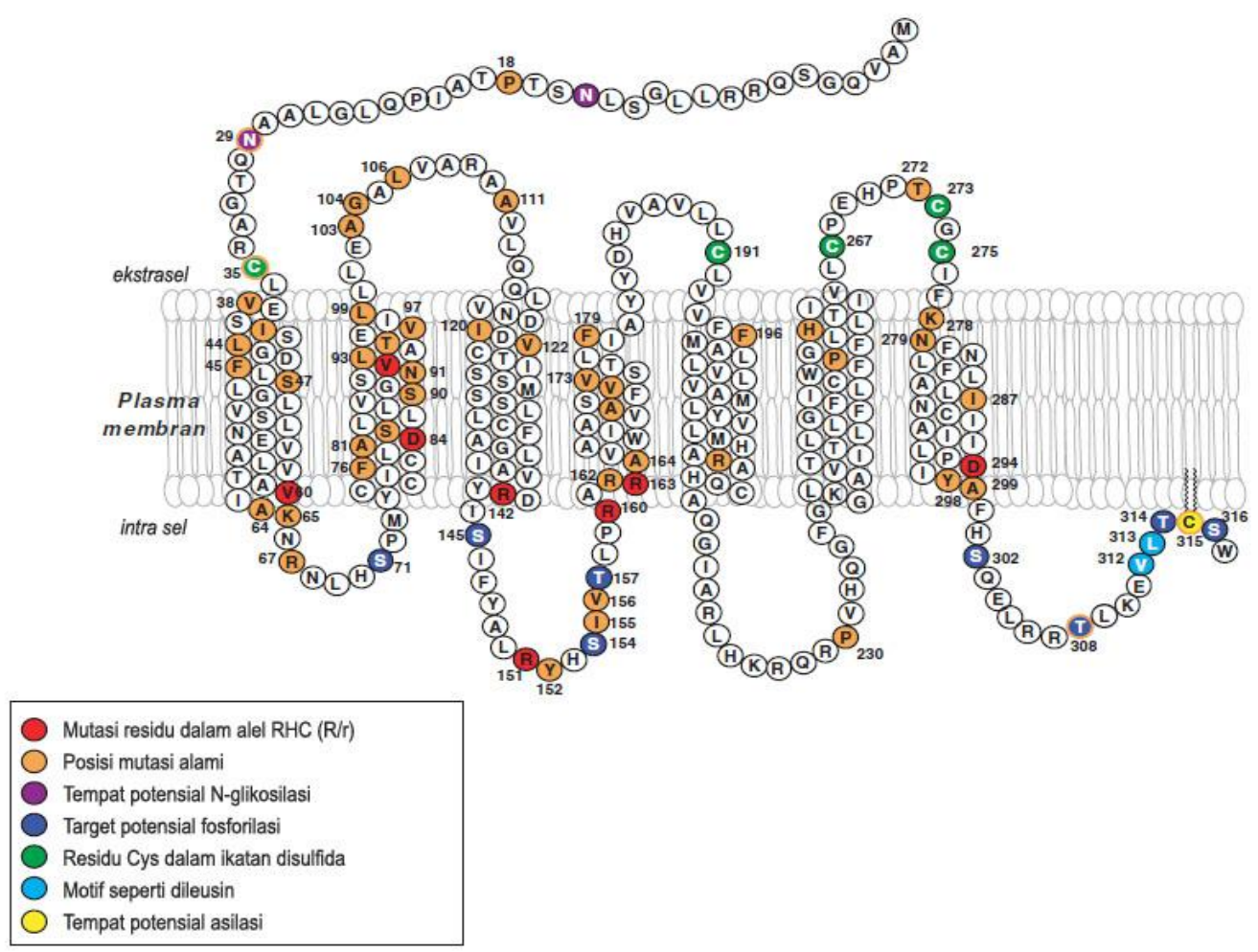

Gambar 3. Struktur protein reseptor melanokortin-1. Tersusun dari 317 residu asam amino dengan ciri khas layaknya GPCR yaitu: N-Terminal ekstra sel, tiga lengkung ekstra sel, tujuh fragmen transmembran, tiga lengkung intra sel dan C-Terminal intra sel. Posisi transmembran heliks disesuaikan sedemikian dalam gambaran model 2D dari Ringholm, dkk, 2004. Sumber: Garcia-Borron JC dkk, 2005. ${ }^{17}$

${ }^{29} \mathrm{NQTG}^{32}$, yang ditunjukkan dengan adanya electrophoretic mobility shift pada kedua sekuens tersebut saat terjadinya glikosilasi. $^{17}$

\section{Lengkung ekstrasel}

Lengkung ekstrasel \{extracellular loop (el) \} pada MC1R lebih pendek dari terminal-N dan berhubungan dengan afinitas ikatan terhadap agonis. Pernah dilaporkan bahwa mutasi pada residu Glu269 dan Thr272 ke Alanin pada lengkung ekstrasel 3 (el3) mengakibatkan penurunan afinitas ikatan dengan agonis. Akan tetapi ikatan agonis juga sangat diperhitungkan dari keterlibatan residu aromatik yang terletak pada Trans Membran 6 (TM6). Mutasi pada Cys267 dan Cys275 menjadi Glisin atau Alanin akan mengakibatkan rusaknya struktur. Mutasi pada Cys273 ke Glisin menyebabkan hilang fungsi. Tetapi pada mutan C273A pernah dilaporkan masih dapat mempertahankan potensi pemberi sinyal ditambah lagi C273A bebas dapat memberikan ikatan ligan untuk $\mathrm{Zn}^{2+}$, satu ion metal yang dapat terikat dengan MC1R dan MC4R dan beraksi sebagai setengah agonis atau sebagai penguat agonis. ${ }^{17}$

\section{Lengkung intrasel}

Lengkung intrasel \{intracellular loop (il) \} menyediakan tempat ikatan dengan protein $\mathrm{G}$ dan menjadi target fosforilasi yang diperlukan dalam regulasi pemberi sinyal, internalisasi dan daur. ${ }^{18}$ Sebuah tripeptida ${ }^{141}{ }^{14} Y^{143}$ dikarakteristik sebagai reseptor kelas A, terletak pada bagian antara transmembran 3 (TM3) dan lengkung intrasel 2 (il2) merupakan elemen kritis dimana sering terjadi LOF (loss of function) dari variasi alel $\mathrm{R} 142 \mathrm{H} .{ }^{17}$

\section{Fragmen transmembran (TM) dan celah tempat ikatan agonis}

Fragmen transmembran terletak kurang lebih sama rata dengan permukaan 
membran sel dengan alur berlawan arah jarum jam. Khusus GPCR kelas A, tempat ikatan-ligan adalah daerah yang terletak sedikit di bawah permukaan membran plasma bagian ekstrasel. Letak Glu94 pada TM2, Asp117 dan Asp121 pada TM3 berinteraksi dengan residu Arg pada sekuensi protein hormon peptida alami, \{HFRW (His-PheArg-Trp)\}. ${ }^{17}$

\section{Terminal-C di dalam sitosol}

Ekor MC1R yang berada di dalam sitosol pendek, tersusun atas 19 residu asam amino yang berfungsi untuk:

1. Interaksi kompleks ligan-reseptor dengan G-protein.

2. Koreksi perubahan posisi reseptor pada membran plasma dengan cara asilasi residu sistein dan menyambungkan rantai asil dengan lapisan lemak membran.

3. Memberikan sinyal untuk lalulintas protein intra sel.

Beberapa mutasi atau pengurangan pada bagian ekor MC1R ini akan sangat berpengaruh terhadap ekspresi permukaan membran sel dan afinitas ikatan terhadap agonis. Misalnya pengurangan residu Trp atau tripeptida Cys-Ser-Trp berakibat menurunnya densitas sebanyak $50 \%$ dan $3 \%$ tempat ikatan. ${ }^{17}$

\section{KESIMPULAN}

Melanokortin 1 reseptor adalah suatu polipeptida transmembran pada melanosit yang termasuk dalam turunan keluarga besar reseptor protein $G$ khususnya $G$ alfa stimulated $(\mathrm{G} \alpha-\mathrm{s})$. MC1R di aktifasi oleh ikatan ligan dengan hormon efektor pada tempat tempat tertentu dari susunan asam amino reseptor tersebut. Variasi struktur protein akan menentukan efektifitas ikatan ligan-reseptor dalam mengaktifasi sinyal transduksi selanjutnya. Munculnya variasi struktur protein bisa jadi dikarenakan faktor daya selektif yang memaksanya untuk bersesuaian, seperti contohnya intensitas radiasi matahari. Akan tetapi mekanisme yang pasti masih belum diketahui dan literatur yang ada masih bersifat hipotesa. Hubungan reseptor dengan agonis-antagonisnya, mekanisme sinyal transduksi yang dicetuskannya, dan jalur sintesis polimer melanin oleh pengaruh reseptor melanokortin 1, akan di bahas dalam manuskrip lain pada Jurnal Biomedik volume berikutnya.

\section{DAFTAR PUSTAKA}

1. Scott MC, Wakamatsu K, Ito S, Kadekaro AL, Kobayashi N, Groden J et al. Human melanocortin 1 receptor variants, receptor function and melano-cyte response to UV radiation. J Cell Sci [serial online]. 2002 [dikunjungi 2009 Apr 12]; 115: 2349-55. Diunduh dari: URL:http://jcs.biologists.org/cgi/content/f ull/115/11/2349

2. Suzuki I, Cone RD, Im S, Nordlund J, Abdel-Malek ZA. Binding of melanotropic hormones to the melanocortin receptor mclr on human melanocytes stimulates proliferation and melanogene-sis. Endocrine Soc [serial online]. 1996 [dikunjungi 2009 Apr 12]; 137(5): $1627-$ 33. Diunduh dari: URL: http://endo.endo journals.org/cgi/reprint/137/5/1627.pdf

3. Rees JL. The melanocortin 1 receptor (MC1R): more than just red hair. Pigmen Cell Res [serial online]. 2000 [dikunjungi 2009 Apr 12]; 13: 135-40. Diunduh dari: http://www.derm.med. ed.ac.uk/PDF/morethanjustredhair.pdf

4. Ramanathan, Chandra S, Gopal, Shuba. Polynucleotides encoding a human Gprotein coupled receptor, HGPRBMY39 (US Patent 7198912). Free Patents Online [homepage on the internet] 2007 Apr 3 [dikunjungi 2009 Apr 12]. Diunduh dari: URL: http://www.freepa-tentsonline.com/ 7198912.html.

5. Le Pape E, Passeron T, Giubellino A, Valencia JC, Wolber R, Hearing VJ. Microarray analysis sheds light on the dedifferentiating role of agouti signal protein in murine melanocytes via the Mc1r. PNAS. [serial online]. 2009 Feb 10 [dikunjungi 2009 Apr 12]; 106(6): $1802-$ 7. Diunduh dari: DOI: 10.1073/ pnas.0806753106.

6. Cormack DH. Ham histology. Jilid I, ed $9^{\text {th }}$. Jakarta: EGC, 1994; p.133.

7. The GeneCards Human Gene Database. Melanocortin 1 receptor (alpha melanocyte stimulating hormone receptor). 
GeneCards ${ }^{\circledR}$ Weizmann Institute of Science, 1996-2009. Version 2.40. [homepage on the internet]. 2009 [Dikunjungi 2009 Apr 23]. Diunduh dari: URL: http://www.genecards.org/cgibin/carddisp .pl?gene $=\mathrm{MC} 1 \mathrm{R} \&$ search $=$ multiple + sclero sis\&suff $=\mathrm{txt}$

8. Römpler H, Stäubert C, Thor D, Schulz A, Hofreiter M, Schöneberg T. G protein-coupled time travel: Evolutionary aspects of GPCR research. Molecular Interventions [serial online]. 2007 [dikunjungi 2009 Apr 12]; 7: 17-25, Diunduh dari: URL: http:// molinterv.aspetjournals.org/cgi/content/fu 11/7/1/17? maxtoshow $=\&$ HITS $=10 \&$ hits $=1$ $0 \&$ RESULTFORMAT $=\&$ fulltext $=$ gpcr $\&$ searchid=1\&FIRSTINDEX=10\&resource type $=$ HWFIG

9. Kroeze WK, Sheffler DJ, dan Roth BL. Gprotein-coupled receptors at a glan-ce. Journal of Cell Science [serial online] 2003 [dikunjungi 2009 Apr 12]; 116: 4867-4869. Diunduh dari: URL: http:// jcs.biologists.org/cgi/reprint/116/24/487

10.Michael Riffle. Gene ontologi (GO) term for GPCR. Yeast Resource Centre, YRC Informatics Platform. [homepage on the internet]. 2009 [dikunjungi 2009 Apr 12]. Diunduh dari: URL: www. yeastrc.org/ pdr/viewGONode.do?acc=GO:0004930

11.Scott MC, Wakamatsu K, Ito S, Kadekaro AL, Kobayashi N, Groden $J$ et al. Human melanocortin 1 receptor variants, receptor function and melanocyte response to UV radiation. Journal of Cell Science [serial online]. 2002 [dikunjungi 2009 Apr 12]; 115: 2349-2355. Diunduh dari: URL: http://jcs.bio logists.org/cgi/ content/full/115/11/2349

12. Valverde P, Healy E, Jackson I, Rees JL, Thody AJ. Variants of the melanocyte- stimulating hormone receptor gene are associated with red hair and fair skin in humans. Nat. Genet [serial online]. 1995 [dikunjungi 2009 Apr 12]; 11(3): 328-30. Diunduh dari: doi:10.1038/ng 1195-328. PMID 7581459

13.Wikimedia Foundation, Inc. Melanocortin 1 receptor. Wikipedia ${ }^{\circledR}$ [homepage on the internet]. 2009 [dikunjungi 2009 Apr 12]. Diunduh dari: URL: http://en.wikipedia.org/wiki/Melanocortin _1_receptor

14.Palczewski K, Kumasaka T, Hori T, Behnke CA, Motoshima H, Fox BA et al. Crystal structure of rhodopsin: A G protein-coupled receptor. Science [serial online]. 2000 [dikunjungi 2009 Apr 12]; 289(5480): 739-45. Diunduh dari: doi:10.1126/science.289.5480.739.PMID 10926528

15.Rasmussen SG, Choi HJ, Rosenbaum DM, Kobilka TS, Thian FS, Edwards PC et al. Crystal structure of the human $\beta 2$-adrenergic G-protein-coupled receptor. Nature [serial online]. 2007 [dikunjungi 2009 Apr 12]; 450 (7168): 383-7. Diunduh dari: doi:10.1038/nature06325. PMID17952055

16.Wikimedia Foundation, Inc. G proteincoupled receptor. Wikipedia ${ }^{\circledR}$ [homepage on the internet]. 2009 [dikunjungi 2009 Apr 12]. Diunduh dari: URL: http://en. wikipedia.org/ wiki/G_proteincoupled_receptor

17.Garcia-Borron JC, Sanchez-Laorden BL, Jimenez-Cervantes C. Melano-cortin-1 receptor structure and functional regulation. Pigment Cell Res [serial online]. 2005 [dikunjungi 2009 Apr 12]; 18: 393-410. Diunduh dari: URL: http://www3.interscience.wiley.com/cgibi $\mathrm{n} /$ fulltext/118701451/ PDFSTART. 